
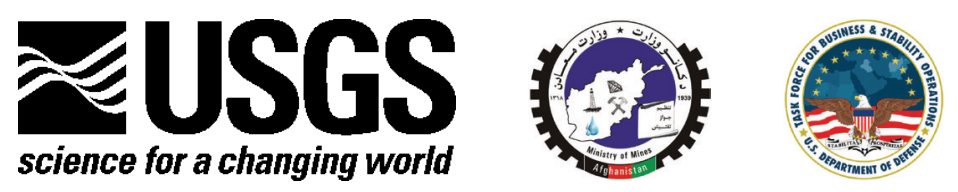

Prepared in cooperation with the Afghanistan Geological Survey under the auspices of the U.S. Department of Defense Task Force for Business and Stability Operations

\title{
Topographic and Hydrographic GIS Datasets for the Afghanistan Geological Survey and U.S. Geological Survey 2014 Mineral Areas of Interest
}

By Jessica D. DeWitt, Peter G. Chirico, and Katherine C. Malpeli

Open-File Report 2015-1181

USGS Afghanistan Project Product No. 336

U.S. Department of the Interior

U.S. Geological Survey 


\section{U.S. Department of the Interior \\ SALLY JEWELL, Secretary}

\section{U.S. Geological Survey \\ Suzette M. Kimball, Acting Director}

U.S. Geological Survey, Reston, Virginia: 2015

For more information on the USGS—-the Federal source for science about the Earth, its natural and living resources, natural hazards, and the environment-visit http://www.usgs.gov/ or call 1-888-ASK-USGS (1-888-275-8747).

For an overview of USGS information products, including maps, imagery, and publications, visit http://www.usgs.gov/pubprod/.

Any use of trade, firm, or product names is for descriptive purposes only and does not imply endorsement by the U.S. Government.

Although this information product, for the most part, is in the public domain, it also may contain copyrighted materials as noted in the text. Permission to reproduce copyrighted items must be secured from the copyright owner.

Suggested citation:

DeWitt, J.D., Chirico, P.G., and Malpeli, K.C., 2015, Topographic and hydrographic GIS datasets for the Afghanistan Geological Survey and U.S. Geological Survey 2014 mineral areas of interest: U.S. Geological Survey Open-File Report 2015-1181, 27 p., http://dx.doi.org/10.3133/ofr20151181.

ISSN 2331-1258 (online) 


\section{Contents}

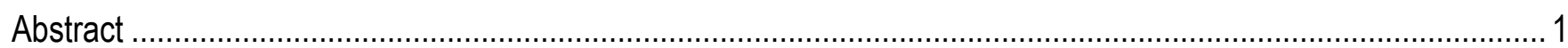

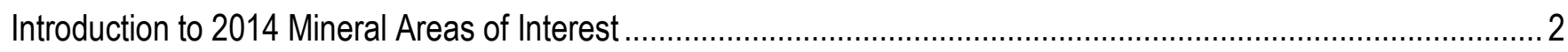

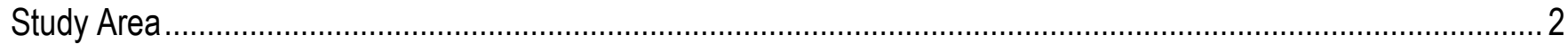

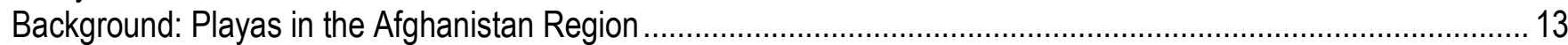

Geomorphological Development and Geologic Composition .................................................................. 13

Hydrologic Modeling in Areas of Low Relief............................................................................................ 14

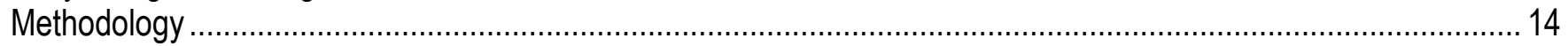

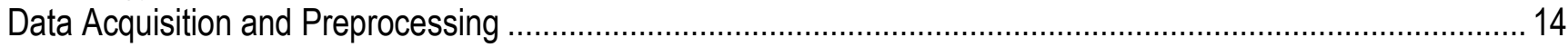

Playa Correction Methodology ………………………………........................................................... 15

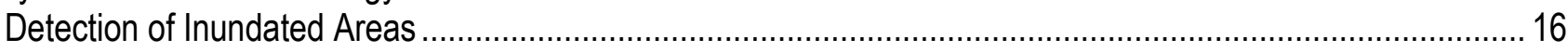

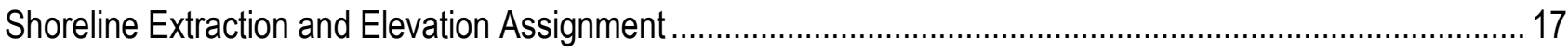

Datasets Derived from the Digital Elevation Models ................................................................................ 18

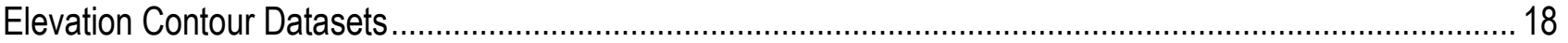

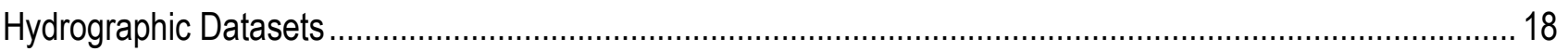

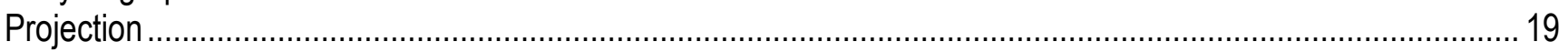

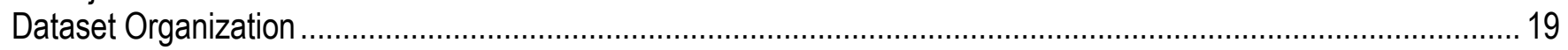

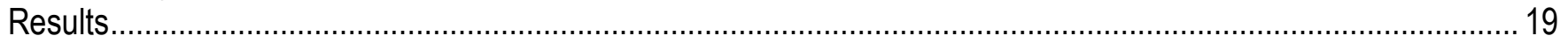

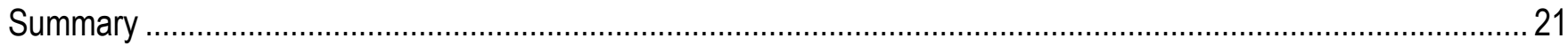

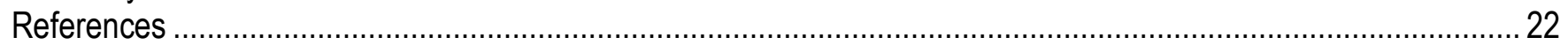

\section{Figures}

1. Map showing previously identified mineral Areas of Interest and newly identified mineral AOls and

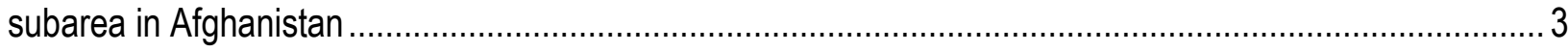

2. Map showing the areal extent and location of the Central Bamyan mineral subarea in Afghanistan ............. 4

3. Map showing the areal extent and location of the Dasht-e-Nawar mineral AOI in Afghanistan .....................5

4. Map showing the areal extent and location of the Farah mineral AOI in Afghanistan .................................. 6

5. Map showing the areal extent and location of the North Ghazni mineral AOl in Afghanistan ........................ 7

6. Map showing the areal extent and location of the South Ghazni mineral AOI in Afghanistan........................ 8

7. Map showing the areal extent and location of the Chakhansur mineral AOI in Afghanistan .......................... 9

8. Map showing the areal extent and location of the Godzareh East mineral AOI in Afghanistan.................... 10

9. Map showing the areal extent and location of the Godzareh West mineral AOI in Afghanistan.................... 11

10. Map showing the areal extent and location of the Namaksar-e-Herat mineral AOI in Afghanistan .............. 12

11. Example of playa areas in the Chakhansur Area of Interest comparing GDEM data and the modified DEM

\section{Tables}

1. Area and elevation results for each individual mineral Area of Interest and subarea.

2. Area, number of vector stream segments, and stream density classified into stream orders 1 to 6 , for each individual mineral Area of Interest and subarea 


\title{
Topographic and Hydrographic GIS Datasets for the Afghanistan Geological Survey and U.S. Geological Survey 2014 Mineral Areas of Interest
}

\author{
By Jessica D. DeWitt, Peter G. Chirico, and Katherine C. Malpeli
}

\begin{abstract}
Mineral extraction and associated industries play an important role in the Afghan economy, particularly in the "transitional era" of declining foreign aid and withdrawal of foreign troops post 2014. In addition to providing a substantial source of government revenue, other potential benefits of natural resource development include boosted exports, employment opportunities, and strengthened industrialization (Joya, 2012). Continued exploration and investment in these industries has resulted in large economic improvements since 2007, when this series of studies was initiated. At that time, the "Preliminary Non-Fuel Mineral Resource Assessment of Afghanistan" was completed by members of the U.S. Geological Survey and Afghanistan Geological Survey (Peters and others, 2007). The assessment published a series of country-wide datasets, including a digital elevation model (DEM), elevation contours, hydrography, transportation routes, geophysics, and cultural datasets (Peters and others, 2007). It also delineated 20 mineralized areas for further study using a geologic-based methodology. A second data product, "Summaries of Important Areas for Mineral Investment and Production Opportunities of Nonfuel Minerals in Afghanistan," was released by Peters and others in 2011. This work highlighted geologic, geohydrologic, and hyperspectral studies that were carried out in specific Areas of Interest (AOIs) to assess the location and characteristics of mineral resources. Also included in the 2011 publication is a collection of appendixes and inventories of Geographic Information System (GIS) datasets for each of the 24 identified AOIs. A third data product was released in 2013 (Casey and Chirico, 2013), publishing datasets for five different AOIs, two subareas, and one AOI extension. Each dataset contains vector shapefiles of the AOI boundary, streams, roads, and contours at 25-, 50-, and 100-meter (m) intervals, as well as raster files of the AOI's DEM and hillshade.

This work represents the fourth installment of the series, and publishes a dataset of eight new AOIs and one subarea within Afghanistan. These areas include Dasht-e-Nawar, Farah, North Ghazni, South Ghazni, Chakhansur, Godzareh East, Godzareh West, and Namaksar-e-Herat AOIs and the Central Bamyan subarea of the South Bamyan AOI (datasets for South Bamyan were published previously in Casey and Chirico, 2013). For each AOI and subarea, this dataset collection consists of the areal extent boundaries, elevation contours at 25-, 50-, and 100-m intervals, and an enhanced DEM. Hydrographic datasets covering the extent of four AOIs and one subarea are also included in the collection. The resulting raster and vector layers are intended for use by government agencies, developmental organizations, and private companies in Afghanistan to support mineral assessments, monitoring, management, and investment.
\end{abstract}




\section{Introduction to 2014 Mineral Areas of Interest}

Afghanistan's mineral resources, including copper, iron, rubies, emeralds, gold, silver, bauxite, and lithium contribute substantially to the country's economic growth, employment, and security development (Joya, 2012). In 2007, Peters and others produced an assessment of Afghanistan's non-fuel mineral resources identifying specific Areas of Interest (AOIs) for future mineral exploration. Referred to as mineral AOIs, these regions represent areas of high mineral potential and are the focus of geologic, geohydrologic, and hyperspectral study and data collection. Twenty-four new mineral AOIs were identified by Peters and others in 2011. A set of GIS data layers was created for each AOI, and includes digital elevation models (DEMs), elevation contours, AOI extent, and hydrographic datasets (previously published in Chirico and Moran, 2011). Five additional mineral AOIs and two subareas were identified in 2012 by project scientists, and a similar set of datasets was published for each of these in 2013 (Casey and Chirico, 2013). As a continuation of the project, eight new mineral AOIs and one subarea are identified in this report. The Central Bamyan subarea of the South Bamyan AOI (from Chirico and Moran, 2011), Farah AOI, North Ghazni AOI, and South Ghazni AOI were determined via hyperspectral anomalies. The Dasht-e-Nawar, Chakhansur, Godzareh East, Godzareh West, and Namaksar-e-Herat AOIs include dry lakes with evaporate mineral potential. A set of GIS layers (presented here) was produced for all AOIs and the Central Bamyan subarea. DEMs for the areas were developed based on Casey and Chirico (2013), however the methodology used to develop the DEMs in the Chakhansur, East Godzareh, West Godzareh and Namaksar-e-Herat AOIs was modified to accommodate their low relief and intermittent inundation. Figure 1 shows a map of all previously identified mineral AOIs, as well the eight AOIs and one subarea that are the focus of this publication.

\section{Study Area}

The study area for this report includes eight mineral AOIs and one subarea. Previous publications (Chirico and Moran 2011, Casey and Chirico 2013) have published similar datasets for other AOIs in Afghanistan. The names of the individual AOIs and subarea reflect the provinces in which they are located, though many extend across several provinces. The Central Bamyan subarea is located in east-central Afghanistan, and is split between the provinces of Wardak and Bamyan (fig. 2). The Dasht-e-Nawar AOI is also located in east-central Afghanistan, but in the Ghazni province (fig. 3). The Farah AOI is located in west-central Afghanistan in the Farah province (fig. 4). Five subareas of the Farah AOI were identified by King and others (2014), but are too small to warrant the production of separate GIS layers. Like the Dasht-e-Nawar AOI, the North Ghazni AOI is located in east-central Afghanistan, primarily in the Ghazni province, but it also crosses into the Wardak province (fig. 5). The South Ghazni AOI is located in east-central Afghanistan, but lies entirely in the Ghazni province (fig. 6). The Chakhansur AOI is located in western Afghanistan primarily in the northern part of the Nimroz province, but also crosses into the Farah province (fig. 7). The Godzareh East and Godzareh West AOIs are located in southern Afghanistan in the southern part of the Nimroz province (figs. 8, 9). The Namaksar-e-Herat AOI is located in western Afghanistan in the Herat province (fig. 10). 


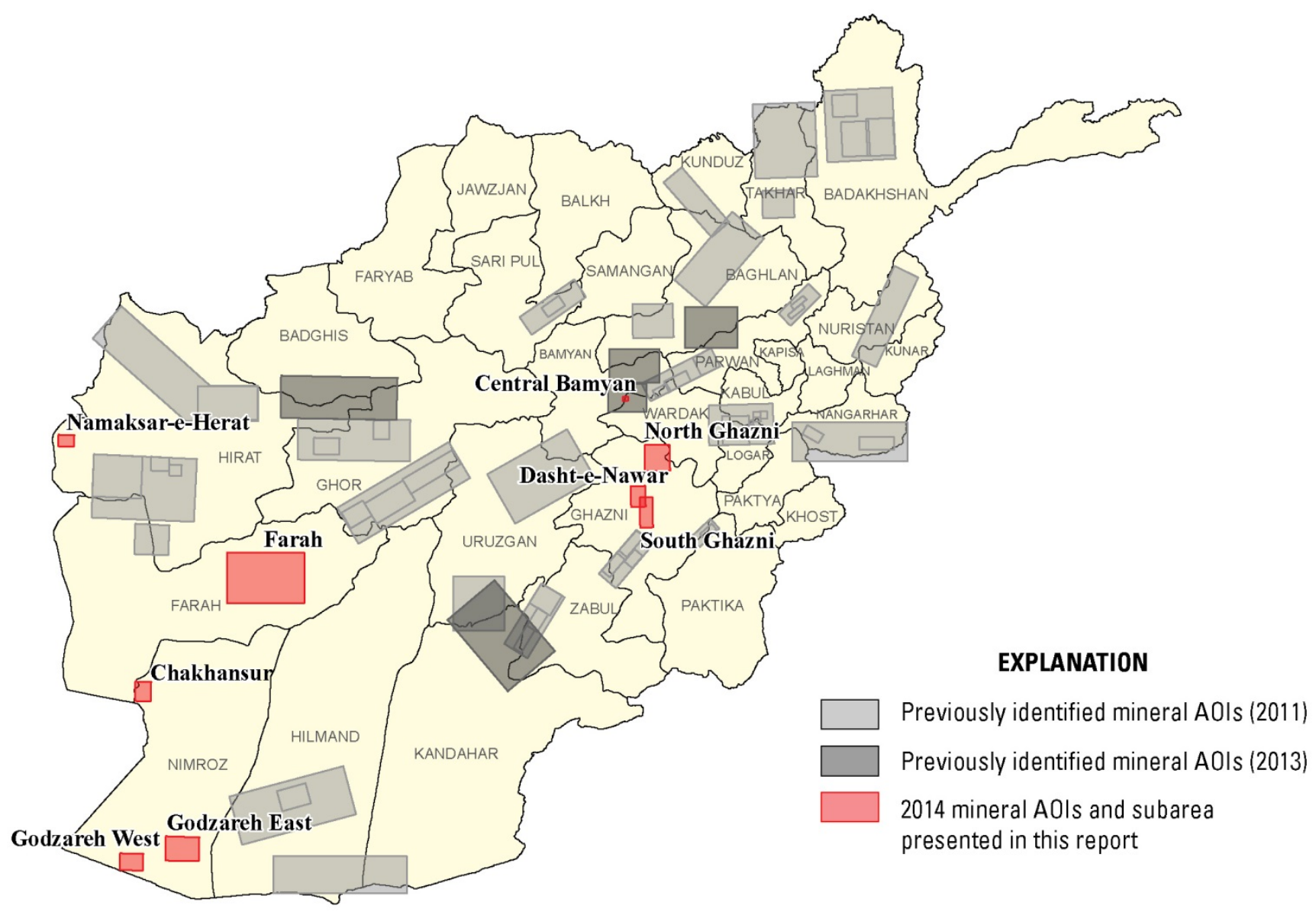

Figure 1. Map showing previously identified mineral Areas of Interest (AOls) and newly identified mineral AOls and subarea in Afghanistan. Smaller boxes shown within some AOls are previously identified subareas (Peters and other, 2011). 


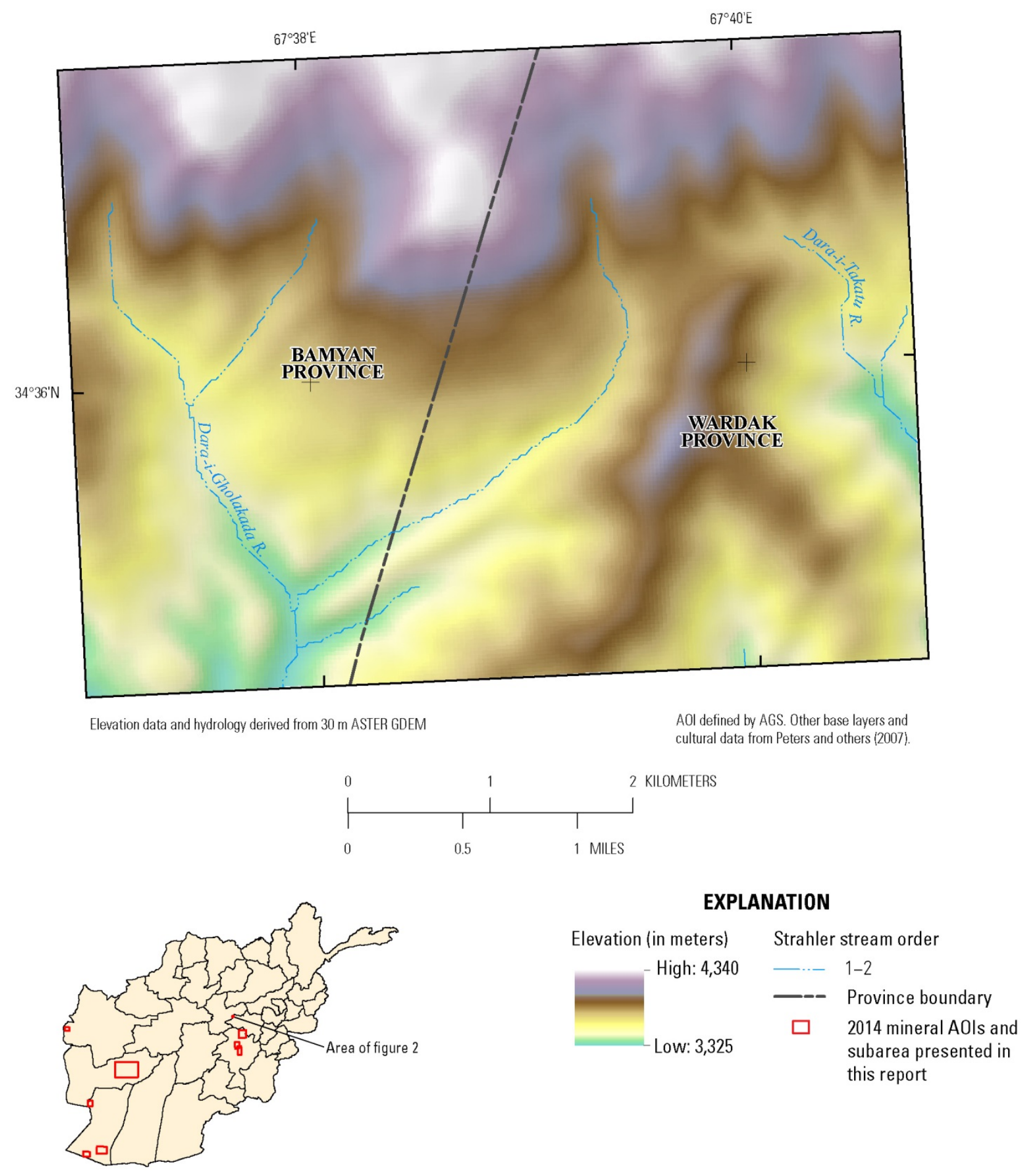

Figure 2. Map showing the areal extent and location of the Central Bamyan mineral subarea in Afghanistan. 

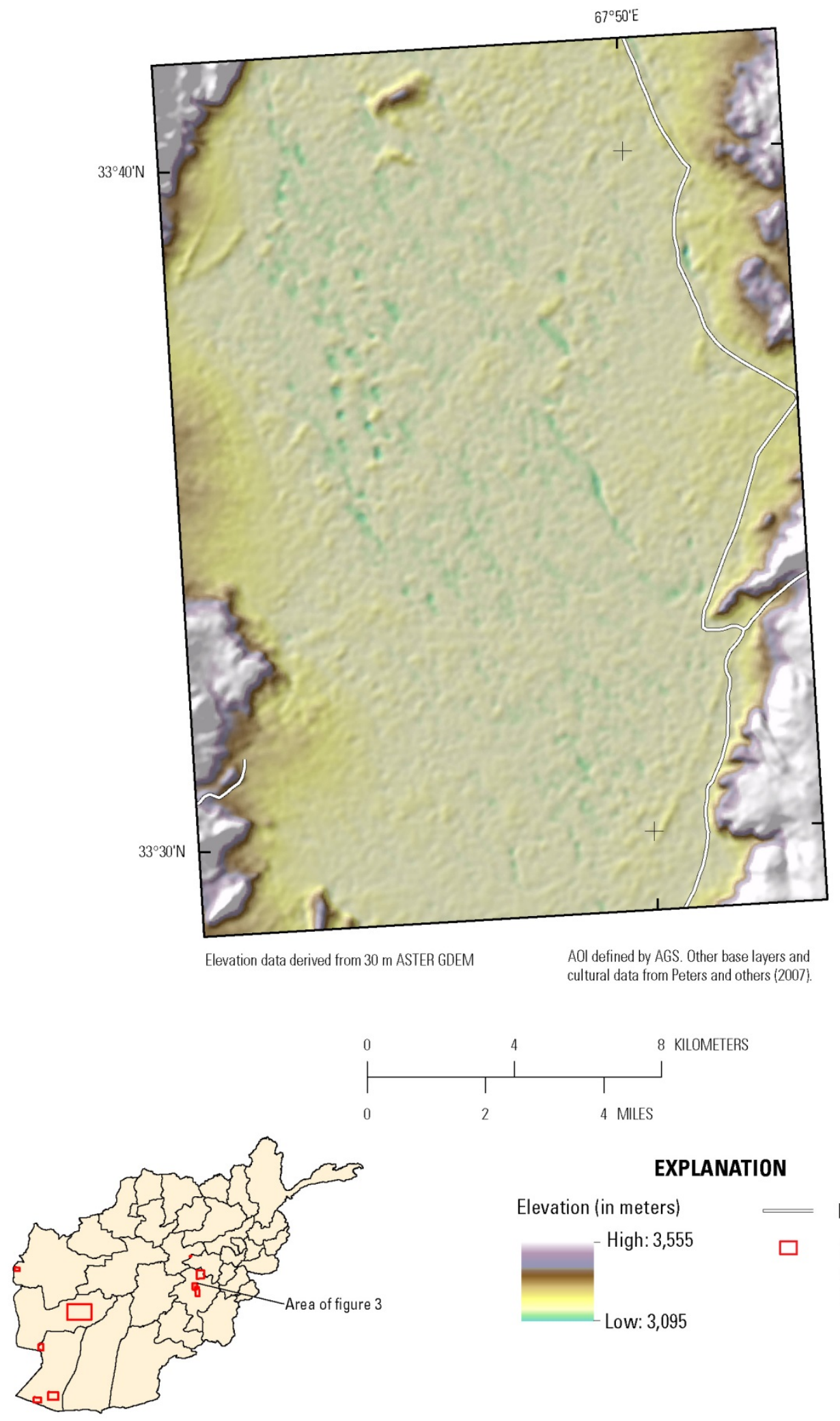

EXPLANATION

Elevation (in meters) $\quad$ Roads

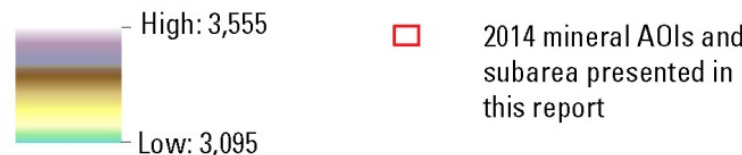

Figure 3. Map showing the areal extent and location of the Dasht-e-Nawar mineral AOI in Afghanistan. 

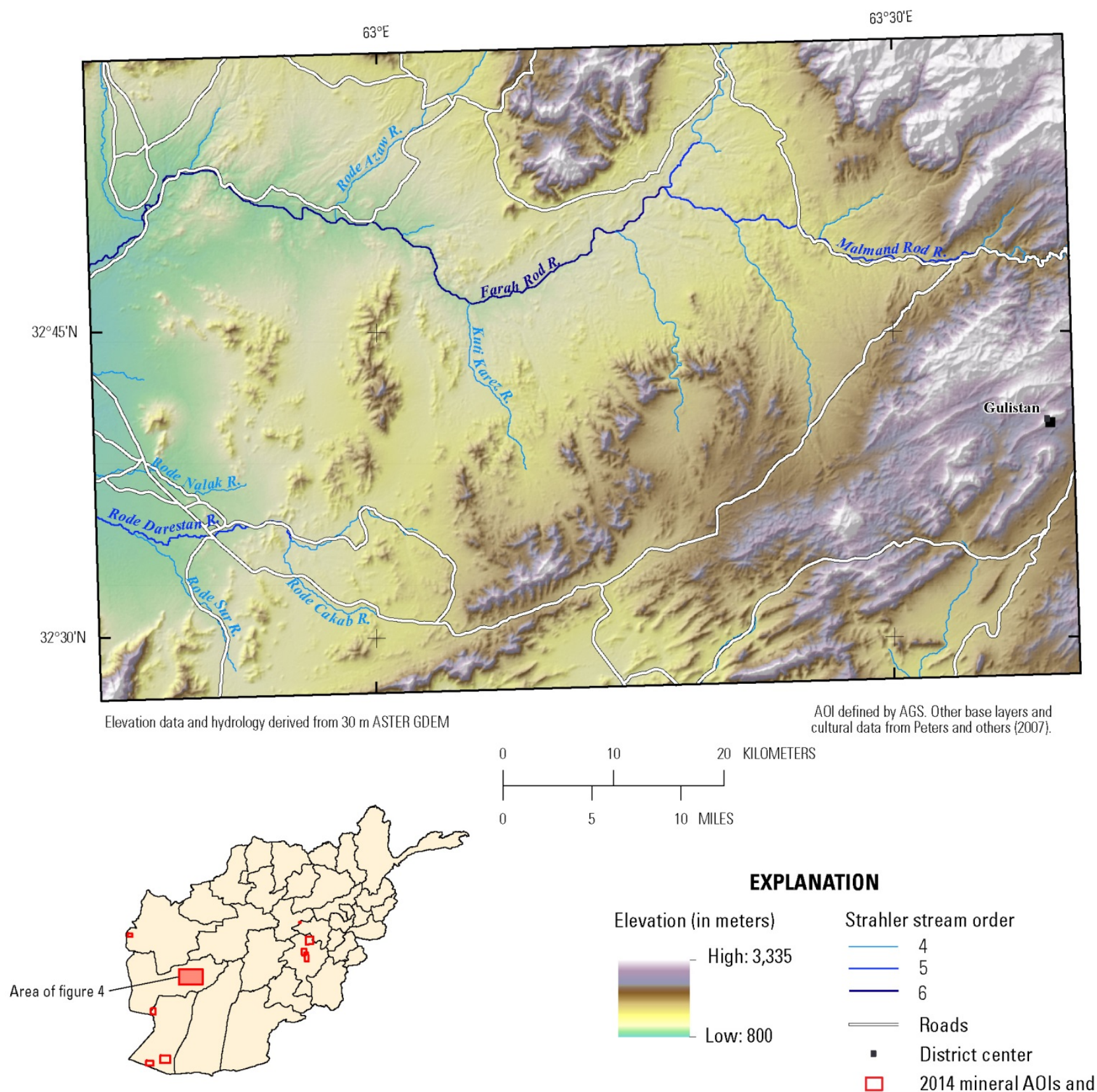

\section{EXPLANATION}

Elevation (in meters) Strahler stream order

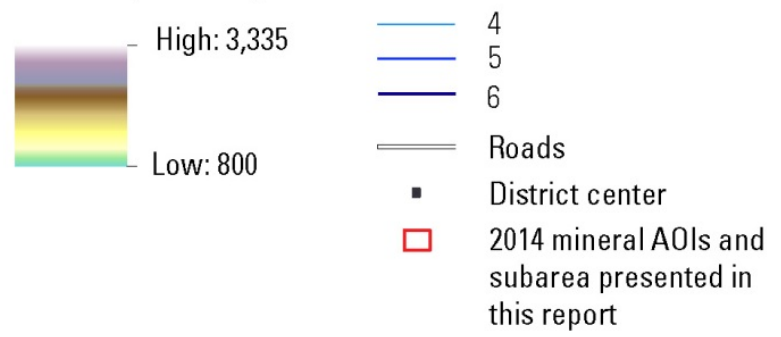

Figure 4. Map showing the areal extent and location of the Farah mineral AOI in Afghanistan. 


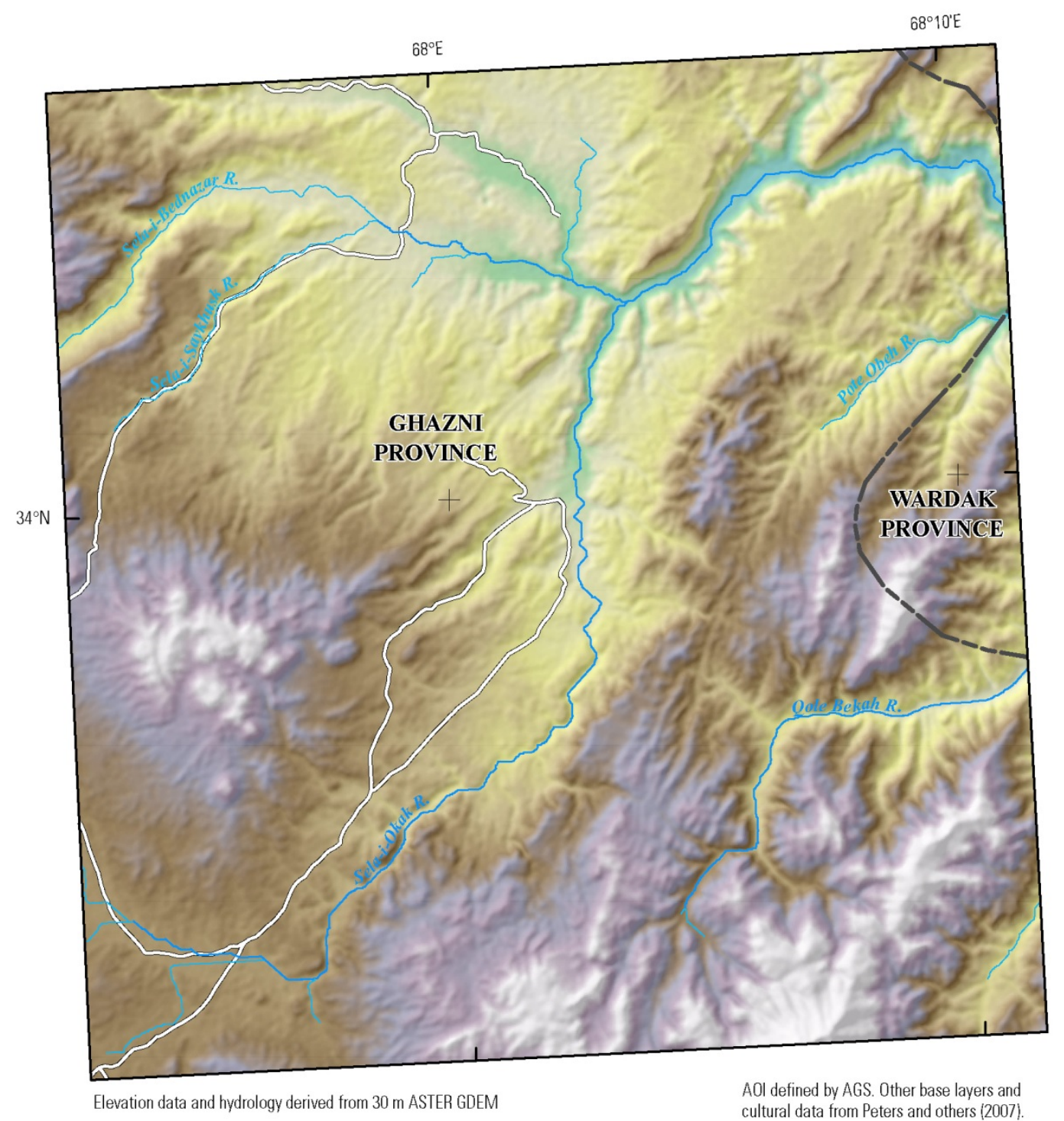

Elevation data and hydrology derived from $30 \mathrm{~m}$ ASTER GDEM cultural data from Peters and others (2007)
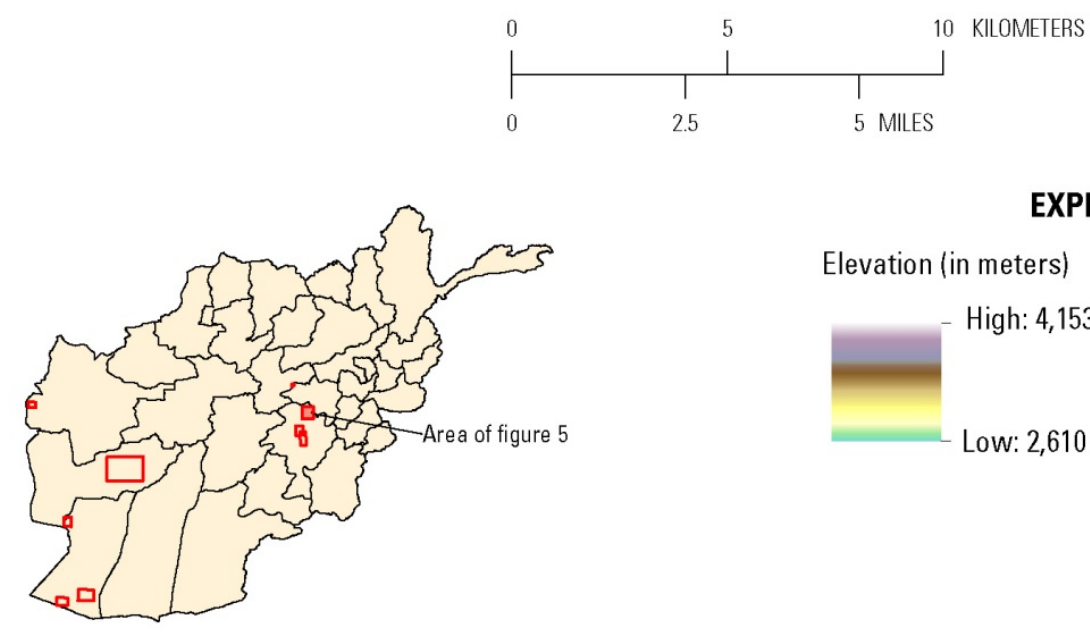

EXPLANATION

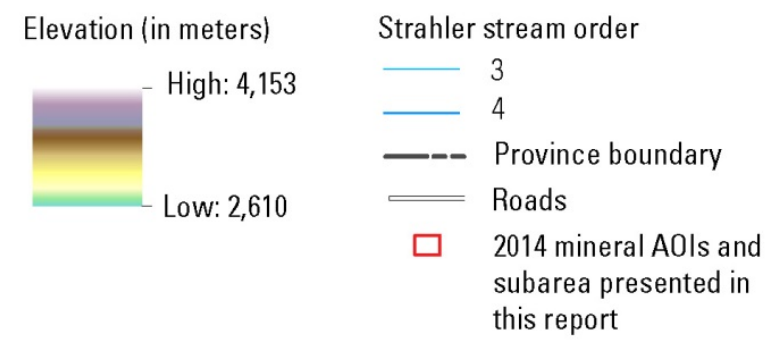

Figure 5. Map showing the areal extent and location of the North Ghazni mineral AOI in Afghanistan. 


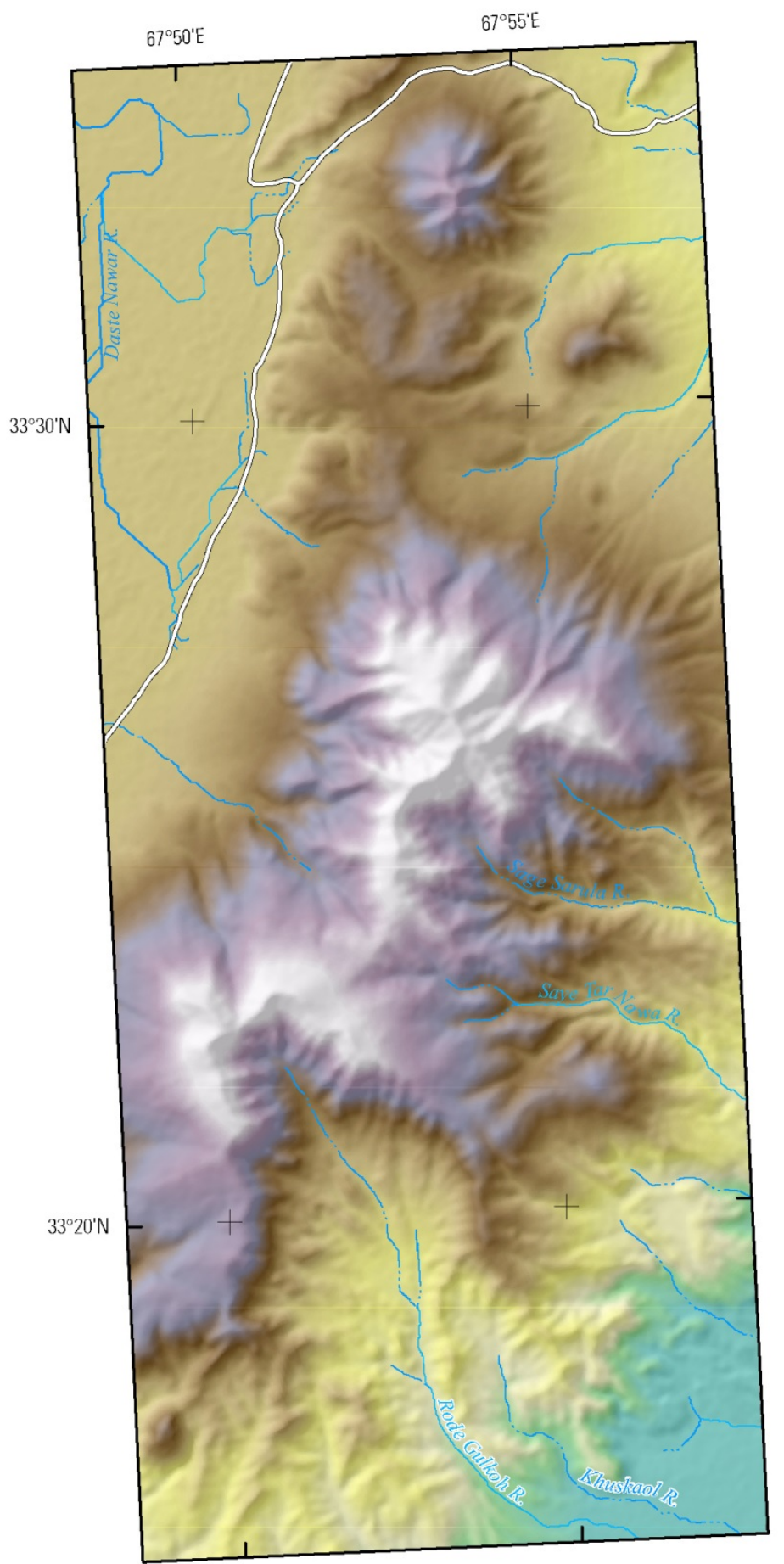

\section{EXPLANATION}

Strahler stream order

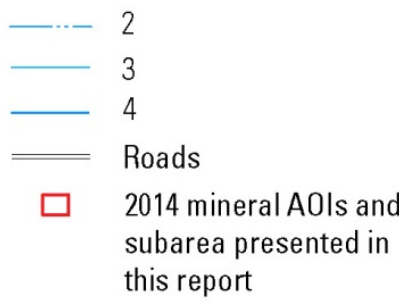

Elevation (in meters)
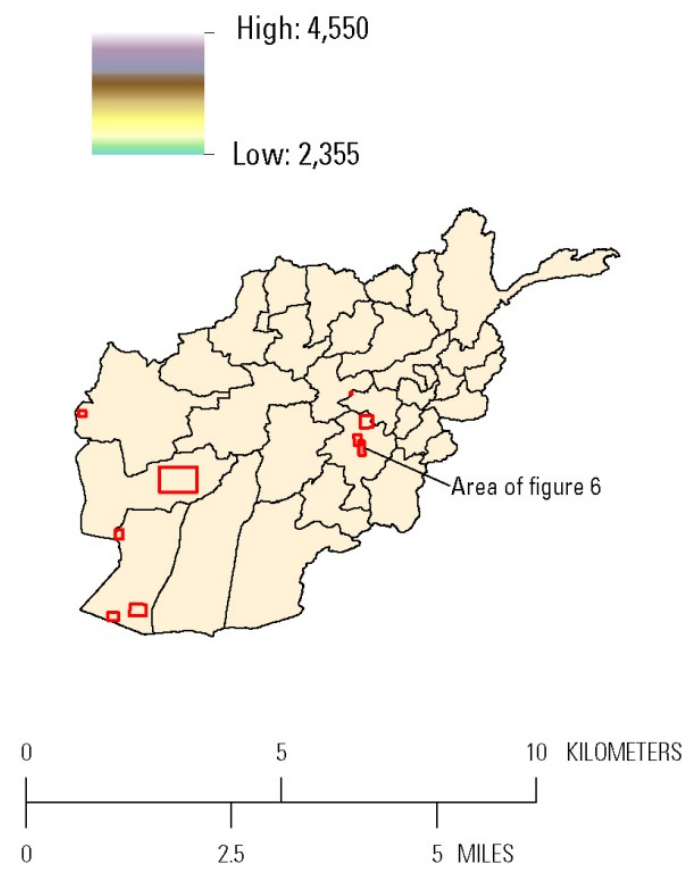

Elevation data and hydrology derived from $30 \mathrm{~m}$ ASTER GDEM. AOI defined by AGS. Other base layers and cultural data from Peters and others (2007).

Figure 6. Map showing the areal extent and location of the South Ghazni mineral AOI in Afghanistan. 
$61^{\circ} 45^{\prime} \mathrm{E}$
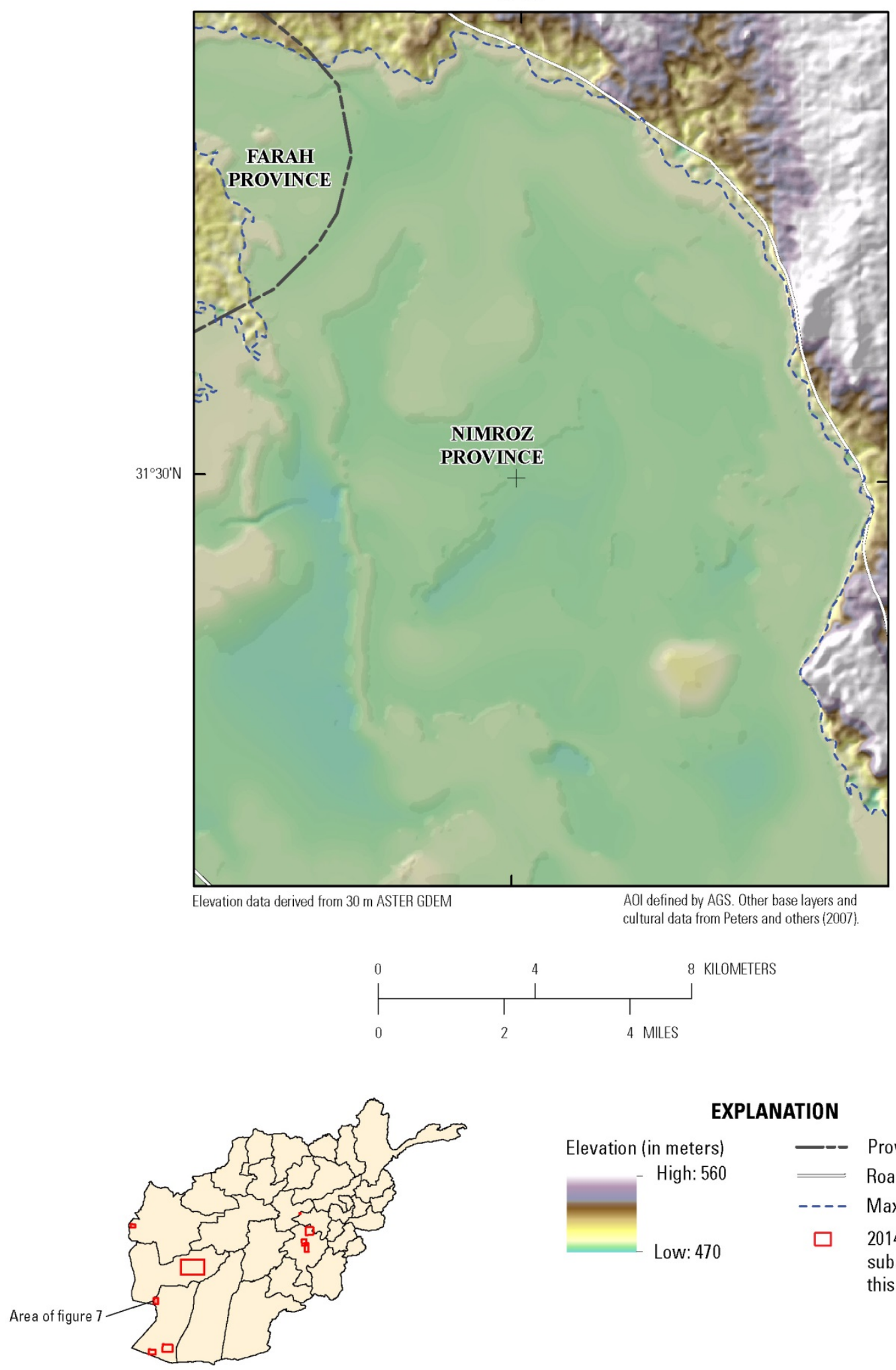

\section{EXPLANATION}

Elevation (in meters) _ _- Province boundary High: $560 \quad$ Roads

Maximum playa extent 2014 mineral AOIs and subarea presented in this report

Figure 7. Map showing the areal extent and location of the Chakhansur mineral AOI in Afghanistan. 


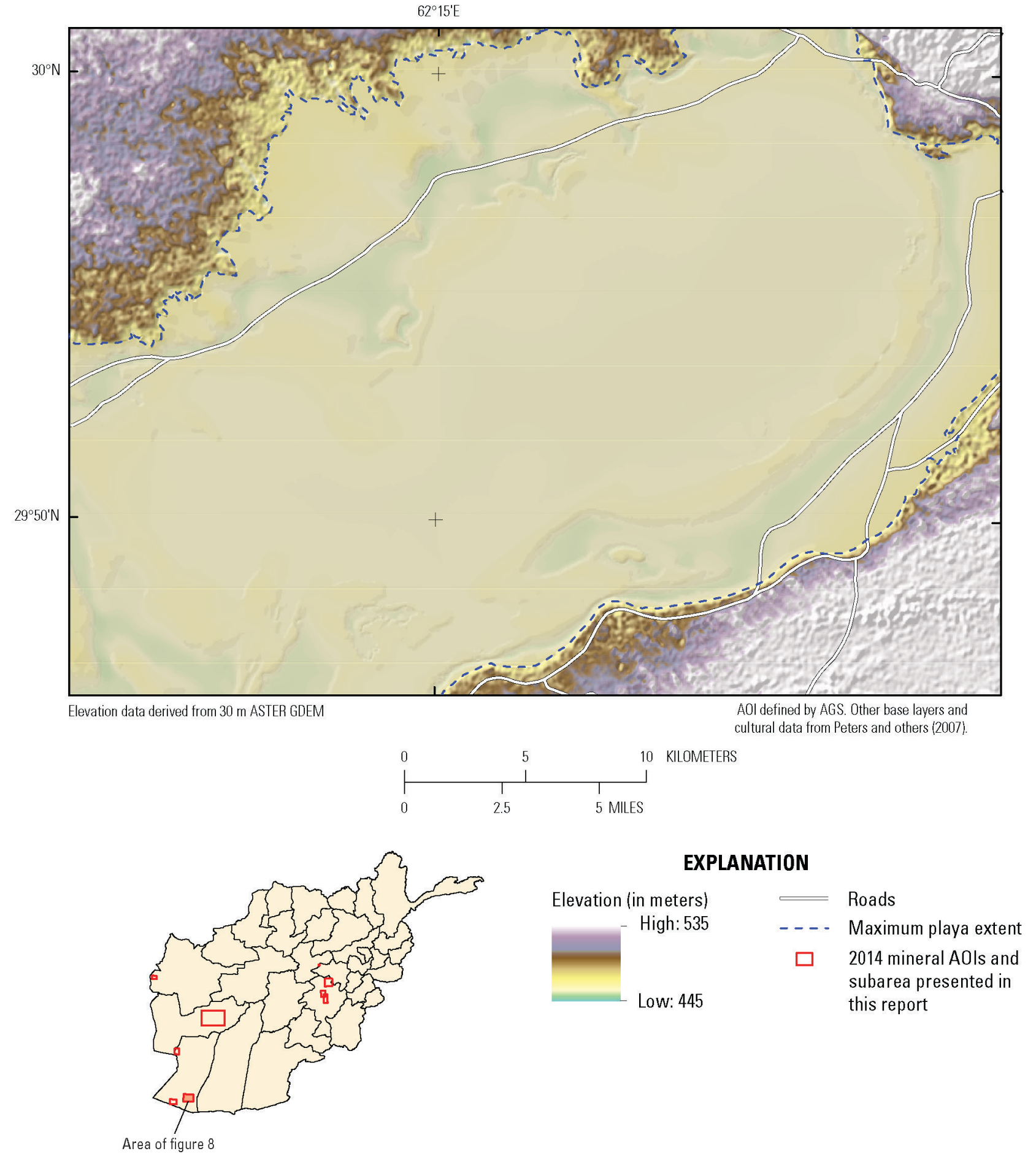

Figure 8. Map showing the areal extent and location of the Godzareh East mineral AOI in Afghanistan. 


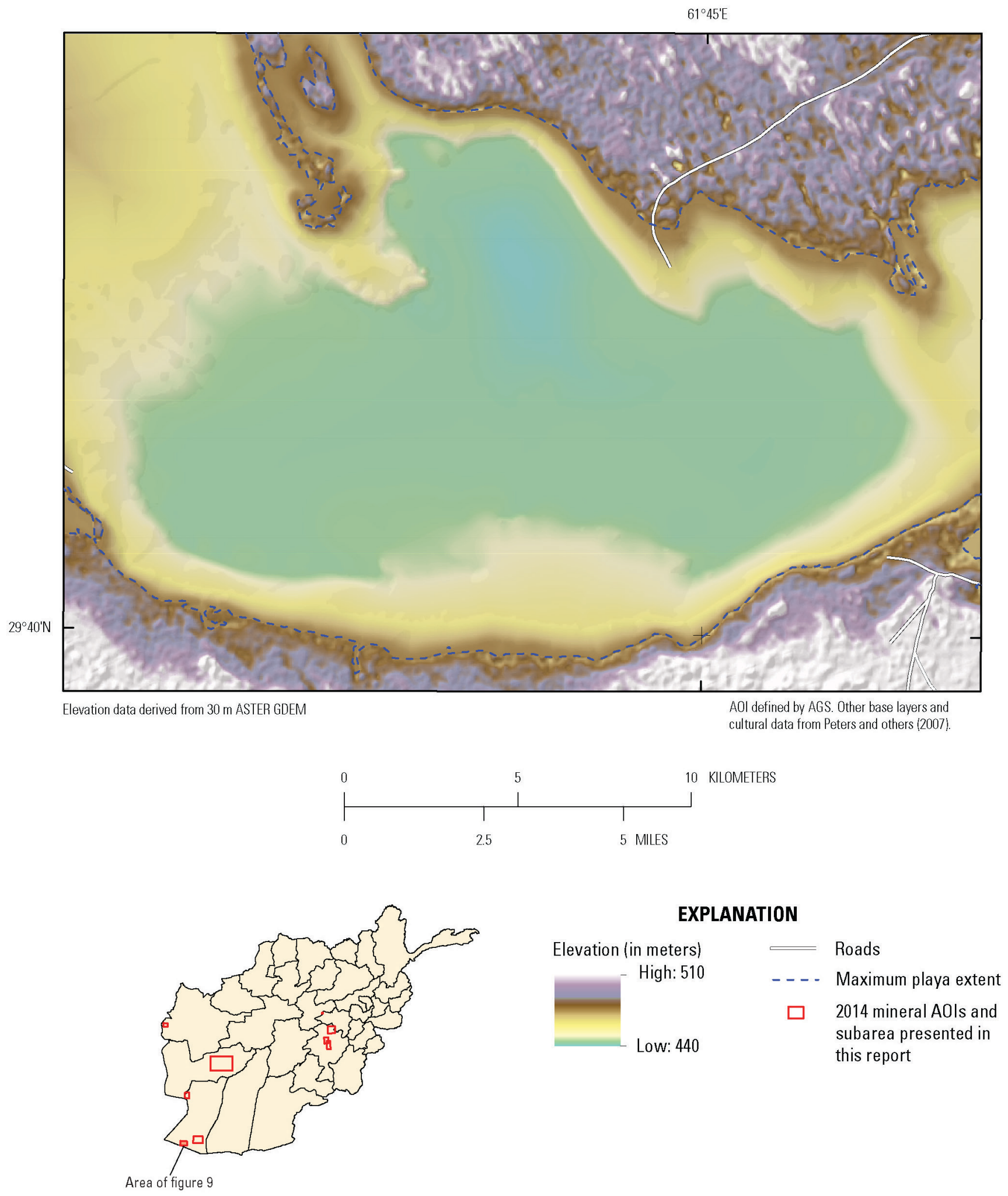

Figure 9. Map showing the areal extent and location of the Godzareh West mineral AOI in Afghanistan. 

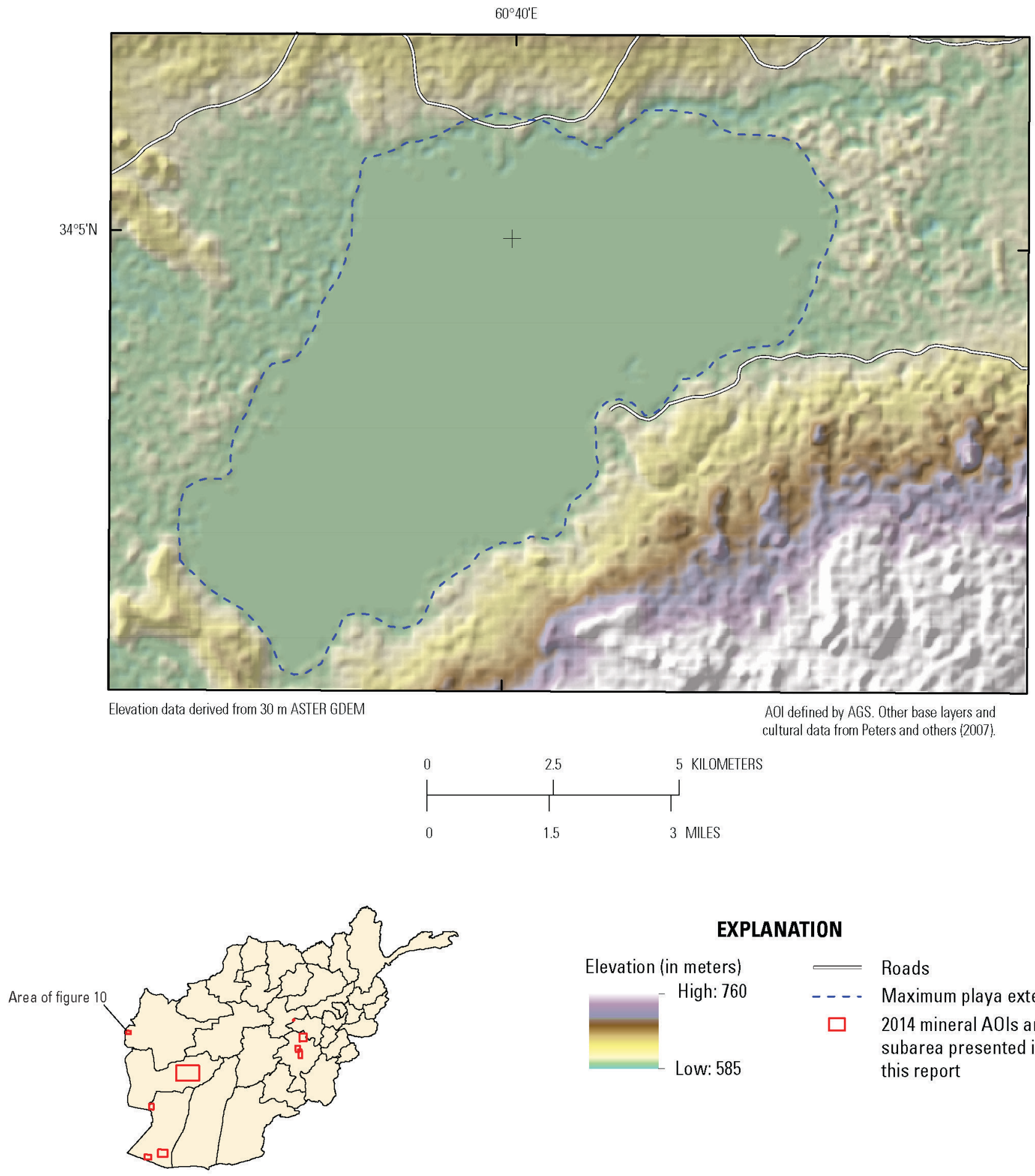

\section{EXPLANATION}

Elevation (in meters) $\quad=$ Roads

$\begin{array}{ccl}\text { High: } 760 & \ldots & \text { Maximum playa extent } \\ & \square & \begin{array}{l}2014 \text { mineral A0ls and } \\ \text { subarea presented in } \\ \text { this report }\end{array} \\ \text { Low: } 585 & \end{array}$

Figure 10. Map showing the areal extent and location of the Namaksar-e-Herat mineral AOI in Afghanistan.

Afghanistan's climate is semi-arid, continental with extensive dry seasons and periods of extreme drought. Generally, the average annual precipitation is 300 millimeters $(\mathrm{mm})$ to $400 \mathrm{~mm}$ per year, with lower elevations typically receiving $100 \mathrm{~mm}$ per year and higher elevations receiving up to $4,000 \mathrm{~mm}$ per year (Lawrimore and Burroughs, 2008). Most of the country's precipitation occurs during 
the winter months in the form of snowfall. Consequently, a large portion of the country's stream systems are ephemeral, and are fed by snowmelt in the spring and early summer months. Afghanistan also contains extensive irrigation canal systems, particularly in the Kandahar and Hilmand provinces, which are used to reroute stream flowpaths to agricultural areas. Several of the 2014 AOIs include lowlying areas that are seasonally flooded. Referred to in various sources as playas, kavir, and sabkhat, these lakes may be up to tens of meters deep, but also may dry up periodically. Additional information about these systems is provided in the section below.

\section{Background: Playas in the Afghanistan Region}

\section{Geomorphological Development and Geologic Composition}

Areas described as pans (Goudie, 1991), endorheic basins (Dorsaz and others, 2013), playas (Briere, 2000), and sabkhat (Briere, 2000), are herein referred to as "playas" (see footnote ${ }^{1}$ for definition of key terms). Playas develop as a result of many interrelated factors and are more prevalent in arid environments. These factors include the amount and duration of precipitation, vegetation growth (or lack of growth), soil structure and composition, and nutrient availability within the soil column. Complex interrelations and positive feedbacks exist between many of the factors, and generally results in the perpetuation of the playa system. For example, irregular magnitude and intensity of precipitation, both seasonally and annually, limits vegetation growth which reduces water penetration into the soil and increases soil susceptibility to erosion (aeolian and hydraulic). Reduced vegetation also increases soil surface temperature, which increases capillary evaporation and results in the formation of evaporites and

${ }^{1}$ Definition of Terms

Daste: an Arabic term that refers to a swamp or marsh-like area that has poorly drained soil and consequently holds substantially more water than soils in the surrounding areas (Casey and Chirico, 2013).

Endorheic basin: a topographic depression that represents a closed system with internal drainage and that has no hydrological connection to nearby marine environments; often located in an arid region. Water inputs to such systems include precipitation, surface inflow, and groundwater recharge, all of which may vary significantly on a seasonal and annual basis. Water outputs are limited to evapotranspiration and groundwater discharge. Other controlling factors include soil texture, groundwater salinity, aeolian processes, and paleoclimates (Dorsaz and others, 2013).

Kavir: a vast closed basin, characterized by an endorheic system (Breckle, 2002).

Pan: a topographic depression caused principally by the deflation of shales or sandstones weakened by salt weathering following desiccation of former lakes, or by capillary evaporation (Goudie, 1991).

Playa: Spanish term meaning "beach" or "shore," used since the late 1800s in the Earth Sciences to refer to periodically inundated mudflats containing wind-supplied mud deposits, and with markings indicative of the flooding-level shorelines (Briere, 2000). In 1975, this definition was modified to describe topographic depressions and dry lake beds occurring in arid regions (Briere, 2000). Briere (2000) robustly defines a playa as "an intercontinental arid zone basin with a negative water balance for over half of each year, dry for over 75 percent of the time, with a capillary fringe close enough to the surface such that evaporation will cause water to discharge, usually resulting in evaporates." This definition sets the term "playa" apart from "playa lake," which is defined as "an arid zone feature, transitional between playa and lake, neither dry more than 75 percent of the time nor wet more than 75 percent of the time. When dry, the basin qualifies as a playa" (Briere, 2000). Playas may be divided into "wet" and "dry" categories, where the former indicates shallow groundwater $(<5 \mathrm{~m}$ depth) allowing for capillary action and evaporates, and the latter indicates $>5 \mathrm{~m}$ depth to groundwater with a dense surface of compact silt and clay (Adams and Sada, 2014).

Sabkha (pl. Sabkhat): an Arabic term used to describe a salt flat, but which is often used synonymously with the geomorphologic term "playa" (Briere, 2000).

Takyr: topographically level, low salinity clay plains which are typically found in alluvial deposition zones, for example in deltas of wadis and rivers (Breckle, 2002).

Other terms often used in similar context, but which are not defined here include: hammadas, serirs, regs, ergs, nebkhas (Breckle, 2002), and salar. 
a duricrust, as well as deflation. Deflation is a geomorphological process by which fine surface sediments are picked up by turbulent wind eddies and carried for long distances (Neuendorf and others, 2005). However, in some systems the development of a duricrust on the surface of the soil may act as a sealant, limiting capillary evaporation. In many cases, groundwater is the primary water input to these systems, and leaves the system only through evapotranspiration. The resultant accumulation of salt evaporites increases weathering of rock parent material, making the parent material more susceptible to deflation processes. However, salt evaporites on the surface of the soil increase the soil's albedo, potentially reducing the temperature reached by the surface soil layers. A high degree of animal activity around any standing water in the depression further complicates and exacerbates these factors, and may result in additional compaction and deflation of the soil surface (Goudie, 1991; Dorsaz and others, 2013).

Playas are frequently covered by immature soils, and much of the soil profile is composed of unconsolidated colluvium or aeolian deposits. Soil profile development is limited by low precipitation, vegetation, and nutrient presence, and soil horizons are often interrupted by petrocalcic horizons containing calcium carbonate, calcium sulfate, or sodium chloride (Breckle, 2002). Salt weathering enhances deflation by producing small grain-size particles, facilitating aeolian transport. In many cases, limited dip angle of the geologic parent material provides substrata that are more conducive to playa development (Goudie, 1991).

\section{Hydrologic Modeling in Areas of Low Relief}

Playas and other seasonally inundated depressions present a particular challenge to topographic elevation modeling. The presence or absence of water in the imagery used to automatically derive ground surface elevation points can significantly impact the quality of the resultant DEM. Within the current study area the following mineral AOIs were observed to have a playa system: Chakhansur, Dasht-e-Nawar, Godzareh East, Godzareh West, and Namaksar-e-Herat. In this report these areas are referred to as the "playa AOIs." These areas appeared speckled in the original DEM, and required a modified methodology for topographic modeling. This modified methodology is described in detail in the Playa Correction Methodology section.

\section{Methodology}

The datasets developed for this project were derived from Advanced Spaceborne Thermal Emission and Reflection Radiometer (ASTER) Global Digital Elevation Model (GDEM) data, with additional processing steps drawn from analysis of Landsat 8 Operational Land Imager (OLI) and Thermal Infrared Sensor (TIRS). Several processes were run on the ASTER GDEM data to produce viable and effective GIS layers. Each new layer produced was clipped to the extent of its corresponding AOI or subarea. All data and GIS processes conducted throughout the creation of this dataset were completed using the Environmental Systems Research Institute's (Esri) ArcMap 10.2 GIS software.

\section{Data Acquisition and Preprocessing}

The ASTER GDEM data were obtained from the National Aeronautical and Space Administration's (NASA) Earth Observing System Data and Information System (EOSDIS) server, where they are publicly available, and consist of 30-meter spatial resolution elevation data. For each new AOI, DEM data were acquired for an area 3 kilometers $(\mathrm{km})$ larger than the AOI extent. This extension of the study area prevented inclusion of edge artifacts in the final datasets, which were clipped to the AOI extent. For the playa AOIs this additional area was extended to $5 \mathrm{~km}$ larger than the AOI 
extent. The EOSDIS server segments GDEM data into tiles to improve the speed of download, and multiple tiles were required for coverage of each AOI. Once downloaded, the tiles for each AOI were mosaicked into a single, continuous grid of elevation values for each study area.

In order to derive functional and aesthetically appealing products from the GDEM data, several DEM preprocessing steps were completed for each AOI and subarea. The raw downloaded DEMs contain elevation values in 16-bit signed integer format (which allows for values from -32,768 to 32,767 ), rounded to the nearest meter. However, several of the products require decimal precision elevation values. Therefore, the DEMs were converted from 16-bit signed integer format to 32-bit floating point data, allowing for sub-meter calculations to be performed. In particular, this conversion is necessary for the calculation of focal statistics, as well as for the generation of smooth hydrological flowpaths and elevation contours. Following the 32-bit float conversion, each DEM was projected into the Universal Transverse Mercator (UTM) zone corresponding to its geographic location using bilinear resampling. Focal statistics were generated of the mean value, using a $5 \times 5$ cell neighborhood. This resulted in a raster dataset whose cell values represent a 24-cell average, reducing local-scale variation and producing a more "smooth" appearance. This focal mean procedure was run a second time on the resultant raster to ensure an even smoother surface free of outliers.

\section{Playa Correction Methodology}

During the processing of the playa AOIs (Chakhansur, Dasht-e-Nawar, Godzareh East, Godzareh West, and Namaksar-e-Herat), it was discovered that large areas of the GDEM model have an inconsistent topographic surface. These areas (like the example shown in figure 11 of the Chakhansur AOI) exhibit large differences in the elevation values of neighboring pixels, visible as speckle in the DEM. Further investigation revealed that these areas correspond to playas in the Afghanistan landscape. The inconsistency of the ASTER GDEM in these areas is a result of their periodic inundation. The ASTER GDEM is created through the autocorrelation of similar pixels in overlapping panchromatic black and white images. In water-covered areas the autocorrelation algorithms often fail to identify similar pixels, resulting in areas of high error or gaps in the output DEM. To minimize these failed areas in the DEM, many image pairs from different collection dates are individually autocorrelated, then combined in the final DEM (Chirico and others, 2012). This inclusion of multiple dates potentially introduces the inconsistency of changing water-levels in the "ground surface" elevation values of the GDEM. For the highly-variable playa lakes of the Afghanistan study areas, this difference is substantial and results in an elevation model that does not accurately reflect the topography of the landscape. This negatively impacts the effectiveness of hydrologic modeling for affected AOIs. Other globally-available DEMs, such as the Shuttle Radar Topography Mission (SRTM) mask-out these problematic areas by assigning a single elevation value equal to the maximum lake-level shoreline. Though this improves the accuracy and appearance of the DEM, it prohibits topographic analyses within the maximum lake-extent area. This study presents a solution to the problem of changing lake levels, based on the detection of lake levels from Landsat imagery and the reassignment of elevation values using the lake-level shorelines from the GDEM. Details of this method are described in the following sections. 


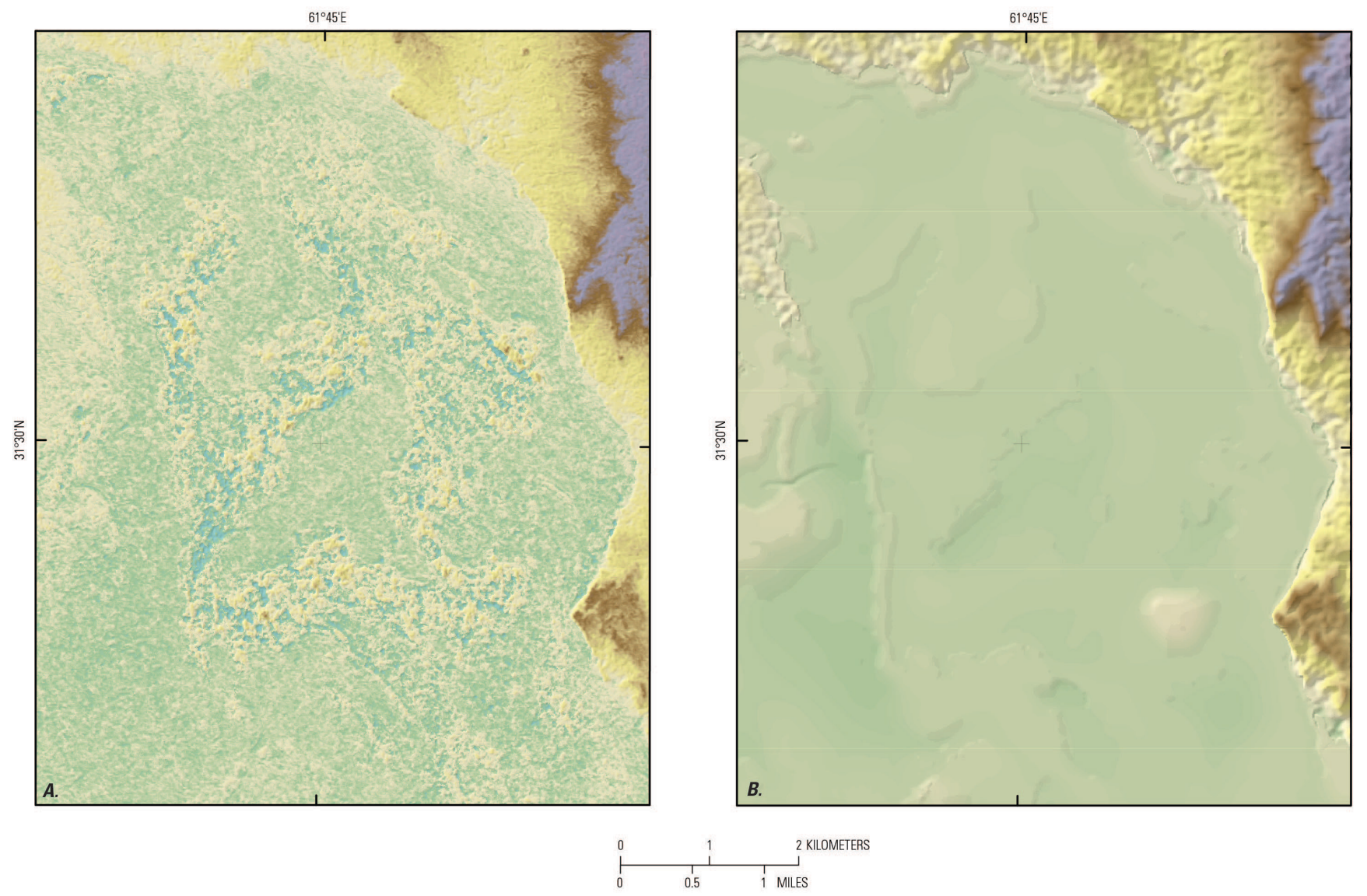

Figure 11. Example of playa areas in the Chakhansur Area of Interest (AOI) comparing GDEM data and the modified DEM. $A$, Speckled appearance of the raw GDEM compared to $B$, the smoothly varying appearance of topography in the modified DEM using the playa correction methodology. The inconsistency of neighboring elevation values shown in $A$ is caused by the inclusion of multiple imagery dates in the GDEM autocorrelation algorithms for a dynamic landscape (in this case, reflecting periodic inundation).

\section{Detection of Inundated Areas}

Imagery from Landsat Multispectral Scanner (MSS), Landsat Thematic Mapper (TM), Landsat Enhanced Thematic Mapper Plus (ETM+), and Landsat 8 OLI and TIRS were used to detect inundated areas in the Chakhansur, Dasht-e-Nawar, Godzareh East, Godzareh West, and Namaksar-e-Herat AOIs. For each AOI, between 5 and 10 images were selected to identify different extents of the lake (hereafter referred to as "lake levels"). Each image was downloaded from the Earth Explorer website (http://earthexplorer.usgs.gov) and preprocessed to create a stacked image with blue, green, red, near infrared (NIR), short-wave infrared (SWIR), and thermal infrared wavelengths. A complete description of Landsat wavelengths and their band assignments is available at http://landsat.usgs.gov/. Each image stack was clipped to an area $5 \mathrm{~km}$ greater than the AOI extent to prevent edge artifacts from influencing the final DEM. 
Inundated (lake) areas of the image were identified using the normalized difference vegetation index (NDVI). This image analysis index is calculated using the equation:

$$
=\frac{N I R-R e d}{N I R+R e d}
$$

where NIR represents the value of the near infrared band for a pixel and Red represents the value of the red band for the same pixel. The NDVI is normally used to identify vegetated areas within the area of interest, and produces a new raster image with values ranging from -1 (representing the absence of vegetation in a pixel) to 1 (representing a fully vegetated pixel). However, NDVI can also be used to identify inundated areas due to the high absorption of NIR wavelengths by water. Flooded areas were identified by manually thresholding the histogram of the NDVI raster into two classes, flooded areas (value 1) and non-flooded areas (value 2). The exact value of the threshold varied for each image, but was identified as a value separating extremely low values (indicating the presence of water) from the higher values (indicating dry land).

In a few of the AOIs, the areas identified in the previous step were considered to be too noisy to produce a functional lake level. In these situations, small areas within the inundated lake were identified as "dry," but did not appear to represent real topographic features that should be captured in the output DEM. A filter using the majority value of eight neighboring cells was applied to the reclassified image. This reduced the number of small inundated and dry areas that were simultaneously captured by the thresholding procedure.

\section{Shoreline Extraction and Elevation Assignment}

The reclassified image was converted into polygons. Additional simplification of the resultant polygons was performed, as necessary, by calculating the area of each polygon and removing those that were less than 100,000 square meters in area. This value represents the area of approximately 33 grid cells, and was judged to be an appropriate cutoff between areas representing the lake and dry land. From the cleaned water and land polygons, a new polygon shapefile was created representing the area of the lake for that Landsat image date. This polygon shapefile was converted to a polyline shapefile representing the shoreline of the lake area. Points were generated along this line for sampling the GDEM.

Elevations from the GDEM were sampled using the shoreline vertices shapefile. The average value of this point sample was calculated and assigned to the shoreline polyline file. This procedure was repeated for all Landsat images collected for each AOI and subarea. The resultant shoreline polyline files and their calculated elevation values were merged together into a polyline file representing contours of the lake bed. These contours were interpolated to a DEM using the Topo to Raster tool, with an output cell size of $30 \mathrm{~m}$, "enforce with sink" drainage enforcement, a discretion error factor of 2 (see footnote $^{2}$ ), and a tolerance 1 of 2.5 (see footnote $^{3}$ ). The generated DEM was clipped to the maximum lake extent.

\footnotetext{
${ }^{2}$ Discretion error factor: parameter in the contour tool in ArcMap (v. 10.1) that controls the amount of smoothing applied to the contours to improve the aesthetic appearance.

${ }^{3}$ Tolerance 1: parameter in the topo to raster tool in ArcMap that reflects the accuracy and density of elevation values in the input dataset compared to the surface drainage. The default for point data inputs is 0 and the default for contour inputs is 2.5 .
} 
To improve the original GDEM for each AOI, the created lake DEM was used to replace spatially corresponding pixels in the original GDEM file.

\section{Datasets Derived from the Digital Elevation Models}

Several datasets were derived from the processed DEMs, including a hillshade to improve visualization of elevation data, contours to add cartographic flexibility in mapping elevation data, and hydrographic data in the form of stream lines.

\section{Elevation Contour Datasets}

Elevation contours were generated at increments of 25,50 , and $100 \mathrm{~m}$ for each AOI and subarea. The elevation contours within the AOIs and subareas were manually edited to remove contours which had been generated around false topographic features as a result of errors in the DEM values.

\section{Hydrographic Datasets}

A series of hydrographic functions was applied to the output of the second focal mean calculation to determine hydrological flowpaths. It is important to note that hydrological flowpaths differ from stream paths in that they do not necessarily contain water. Afghanistan's dry climate translates into mostly ephemeral streams, and many only contain water every few years. The elevation datasets were processed to remove drainage imperfections, referred to as "sinks" using the Fill tool.

Identification of flow direction and flow accumulation was performed on the DEMs, based on the work of Jenson and Domingue (1988). Flow direction is determined by the direction of highest slope, indicated by the largest difference between neighboring cell centers in the raster dataset. When all neighboring cell centers contain the same value (indicating perfectly flat topography), the neighborhood is enlarged until an elevation difference is found. This action forces the flow out of only one cell in a neighborhood. Flow accumulation is correlated to the amount of water that hypothetically would flow through each cell, if precipitation were to fall on the upslope surface (ignoring the potential impact of evaporation, absorption, or other interception). Cells with high flow accumulation values suggest areas of concentrated surface flow, which may be used to identify stream channels. A flow accumulation equal to zero suggests a ridgeline. Flowpaths were derived from the flow accumulation result, based on the work of Tarboton and others (1991), by reclassifying to include an upstream contributing area with a threshold of greater than 1,500 cells. The exact number of cells selected for each AOI and subarea was determined by visual interpretation of the flowpaths overlain on Landsat imagery. Though many of the streams created by this procedure are ephemeral, they are included in the DEM-derived hydrology dataset because they are hydrologically important in the landscape.

Using the reclassified flow accumulation raster, the stream order was determined for the hydrographic channels in the Central Bamyan subarea and the Dasht-e-Nawar, Farah, North Ghazni, and South Ghazni AOIs. Stream ordering is a method of identifying and classifying types of streams based on their number of tributaries. To develop stream orders in this study, the Strahler method was applied (Strahler, 1964). This process quantifies the hydrologic contributions of each branch of the riverine network by assigning a number to each branch based on its upslope flowpaths. A stream order of 1 corresponds to stream segments with no channelized water flow upstream. These are the smallest and shortest stream segments in the network. A second-order stream is created when two first-order streams intersect. A third-order stream is created when two second-order streams intersect, and so on. This system of numbering continues until every segment in the system has been assigned a value. Each stream order suggests a generalized set of flow characteristics, which is important to modeling the 
location of minerals deposited by the stream. Order numbers are directly proportional to the size of the contributing watershed, to channel dimensions, and to stream discharge measurements for each individual stream segment. The larger the stream order, the greater the number of upslope streams or channels that feed into it. The Strahler method is widely accepted and implemented, and in this project it allows for streams to be compared in multiple locations over an extended period of time.

The stream order raster dataset was converted to a shapefile and included as one of the final GIS datasets for each AOI. Streams of order 3 and larger were identified from the stream order raster and used to delineate watersheds. Identification of these larger streams involved reclassifying the stream order raster to exclude streams of order 1 and 2. This exclusion reduced the number of small watersheds and generated larger watersheds significant at the landscape scale. It also reduced the inclusion of ephemeral stream watersheds.

\section{Projection}

All datasets were produced in both the projection World Geodetic System (WGS) 84 Universal Transverse Mercator (UTM), and the geographic coordinate system WGS 1984. Afghanistan is divided into UTM zones $41 \mathrm{~N}, 42 \mathrm{~N}$, and $43 \mathrm{~N}$, and each AOI or subarea was projected into its appropriate UTM zone. The Farah, Chakhansur, Godzareh East, Godzareh West, and Namaksar-e-Herat AOIs are located in UTM zone 41N. The Central Bamyan subarea and the Dasht-e-Nawar, North Ghazni, and South Ghazni AOIs are located in UTM zone 42N.

\section{Dataset Organization}

All datasets produced for each of the eight mineral AOIs and one subarea are contained within a folder labeled with the name of the AOI or subarea, organized into the following subfolders:

Area_Extent, Elevation_Contours, Hydrography, and Topography. The hydrography folder is only included for Central Bamyan, Dasht-e-Nawar, Farah, North Ghazni, and South Ghazni folders due to the lack of streamflow in other AOIs. The Area_Extent folder contains the AOI or subarea boundary. The Topography folder contains two subfolders for the DEM and hillshade. The Elevation_Contours folder contains three subfolders: 25m_Contours, 50m_Contours, and 100m_Contours. Each of these contains shapefiles of the corresponding elevation contours. The Hydrography folder contains both streams and watershed shapefiles. For each dataset (extent boundary, DEM, contours, streams, and watersheds) the folder contains files in both UTM and WGS projections. Also included in each folder and (or) subfolder is metadata, in extensible markup language (.xml) and text file (.txt) format, corresponding to the contents of the folder. Metadata in .xml format is provided in the Federal Geographic Data Committee (FGDC) standard format and in the International Organization for Standardization (ISO) standard format; however, only the FGDC format is converted to a text file. Lastly, a folder entitled AOI_Maps is included with the dataset and contains maps of the eight AOIs and subarea, similar to those shown in the figures of this report, but formatted as Adobe portable document file (.pdf).

\section{Results}

The resulting dataset includes various layers for each AOI, useful for natural resource assessments, monitoring, and management, as well as water resource modeling. A DEM containing ground surface elevation values in meters is included with a hillshade raster to improve visualization of topography. Elevation contours, constructed at intervals of 25, 50, and $100 \mathrm{~m}$ allow for alternative visualizations of topography. Hydrology datasets are provided, including a streams layer attributed with individual stream orders, and a watersheds layer displaying watersheds of stream order 3 or higher. 
Finally, the boundary of the AOI is provided. These layers were created for each of the new mineral AOIs and subarea; however, AOIs that encompass a playa (Chakhansur, Dasht-e-Nawar, Godzareh East, Godzareh West, and Namaksar-e-Herat) do not contain any hydrologic layers, as they represent areas of internal drainage. The watershed layer was also omitted from the Central Bamyan subarea and Dasht-eNawar AOI datasets (no watershed folder), because no third-order streams were present. The flowpaths were designed to be used with maps at a scale of 1:100,000 to 1:50,000. Accuracy of model flowpaths has not been validated for scales falling outside of this range.

Tables 1 and 2 provide elevation and stream order results of the study areas using basic statistics and areal measurements for comparison purposes. The lowest and highest elevation values (table 1) reflect the minimum and maximum elevations (respectively), and the mean elevation reflects the sum of all elevation values in the AOI divided by the total number of DEM cells. The elevation range (table 1) describes the total potential topographic variation within the AOI (difference between the maximum and minimum elevation), and the standard deviation describes the distribution of elevation values around the mean. These last three statistics are particularly helpful in understanding the topography within each AOI. The mean provides information regarding the general height of the DEM (especially when considered in relation to the other AOI mean values). The elevation range and the standard deviation provide information concerning potential outliers that might influence the mean. A relatively large standard deviation would indicate the potential presence of outlier elevation values, and the understanding that the topography may vary substantially across the landscape. The elevation data results displayed in table 1 show that South Ghazni has the highest elevation point $(4,548.07 \mathrm{~m})$, however Central Bamyan has the highest mean elevation $(3,741.07 \mathrm{~m})$. The Farah AOI exhibited the largest elevation range of 2,523.57 m despite a moderate maximum elevation of $3,331.34 \mathrm{~m}$. The standard deviation values in table 1 highlight AOIs with playas, as these AOIs have substantially lower standard deviation than the AOIs without playas.

Table 2 displays the number of stream segments of a specific stream order identified in each AOI and subarea. The maximum identified stream order in all AOIs was a stream order of 6 , located in the Farah AOI. The remaining AOIs contained only order 5 or lower stream segments. Streams were not generated for the playa AOIs (Chakhansur, Godzareh East, Godzareh West, or Namaksar-e-Heart), so these values are blank in table 2. Stream density, calculated as the total area of the AOI divided by the number of stream segments present in the watershed, is a basic measure of the degree to which the landscape is dissected by the stream network. Though it might be expected that all AOIs have a moreor-less similar stream density, the South Ghazni and Dasht-e-Nawar AOIs have substantially higher stream densities than other AOIs in the study. 
Table 1. Area and elevation results for each individual mineral Area of Interest (AOI) and subarea.

$\left[\mathrm{km}^{2}\right.$, square kilometer; $\mathrm{m}$, meter; STD, standard deviation]

\begin{tabular}{lccccrr}
\hline \multicolumn{1}{c}{ AOl or Subarea } & Area $\left(\mathbf{k m}^{2}\right)$ & $\begin{array}{c}\text { Lowest } \\
\text { Elevation }(\mathbf{m})\end{array}$ & $\begin{array}{c}\text { Highest } \\
\text { Elevation }(\mathbf{m})\end{array}$ & $\begin{array}{c}\text { Mean Elevation } \\
(\mathbf{m})\end{array}$ & $\begin{array}{c}\text { Elevation Range } \\
(\mathbf{m})\end{array}$ & STD \\
\hline Central Bamyan & 25.93 & 3326.96 & 4339.07 & 3741.07 & $1,012.11$ & 219.12 \\
Dasht-e-Nawar & 402.19 & 3098.92 & 3552.99 & 3150.21 & 454.07 & 60.14 \\
Farah & 5191.93 & 807.77 & 3331.34 & 1266.10 & $2,523.57$ & 337.90 \\
North Ghazni & 861.59 & 2613.72 & 4153.07 & 3089.78 & $1,539.35$ & 201.47 \\
South Ghazni & 496.32 & 2359.32 & 4548.07 & 3302.53 & $2,188.75$ & 382.14 \\
Chakhansur & 401.98 & 474.05 & 557.14 & 482.61 & 83.09 & 14.45 \\
Godzareh East & 1078.13 & 448.06 & 532.73 & 460.31 & 84.67 & 13.06 \\
Godzareh West & 507.96 & 444.97 & 505.27 & 455.22 & 60.30 & 9.48 \\
Namaksar-e-Herat & 239.97 & 586.12 & 759.3 & 610.99 & 173.18 & 32.54 \\
\hline
\end{tabular}

Table 2. Area, number of vector stream segments, and stream density classified into stream orders 1 to 6 , for each individual mineral Area of Interest (AOI) and subarea.

$\left[\mathrm{km}^{2}\right.$, square kilometer]

\begin{tabular}{lcrrrrrrrr}
\hline \multicolumn{1}{c}{ AOl or Subarea } & $\begin{array}{c}\text { Area } \\
\left.\mathbf{( k m}^{2}\right)\end{array}$ & $\begin{array}{c}\text { Stream } \\
\text { Order 1 }\end{array}$ & $\begin{array}{c}\text { Stream } \\
\text { Order 2 }\end{array}$ & $\begin{array}{c}\text { Stream } \\
\text { Order 3 }\end{array}$ & $\begin{array}{c}\text { Stream } \\
\text { Order 4 }\end{array}$ & $\begin{array}{c}\text { Stream } \\
\text { Order 5 }\end{array}$ & $\begin{array}{c}\text { Stream } \\
\text { Order 6 }\end{array}$ & $\begin{array}{c}\text { Stream } \\
\text { Segments }\end{array}$ & $\begin{array}{c}\text { Stream } \\
\text { Density }\end{array}$ \\
\hline Central Bamyan & 25.93 & 13 & 6 & -- & -- & -- & -- & 19 & 0.73 \\
Dasht-e-Nawar & 402.19 & 193 & 88 & 184 & 71 & 11 & -- & 547 & 1.36 \\
Farah & 5191.93 & 2809 & 1155 & 759 & 285 & 106 & 171 & 5285 & 1.02 \\
North Ghazni & 861.59 & 322 & 201 & 65 & 85 & 17 & -- & 690 & 0.80 \\
South Ghazni & 496.32 & 374 & 208 & 48 & 47 & -- & -- & 677 & 1.36 \\
Chakhansur & 401.98 & -- & -- & -- & -- & -- & -- & -- & -- \\
Godzareh East & 1078.13 & -- & -- & -- & -- & -- & -- & -- & -- \\
Godzareh West & 507.96 & -- & -- & -- & -- & -- & -- & -- & -- \\
Namaksar-e-Herat & 239.97 & -- & -- & -- & -- & -- & -- & -- & -- \\
\hline
\end{tabular}

\section{Summary}

The hydrological flowpaths and elevation contour datasets presented in this report were created based on the processing of the ASTER GDEM data and were evaluated against Landsat imagery. No fieldwork has been completed to date to verify the locations and distribution of the DEM-derived streams or channels relative to the actual streams or channels on the ground. Because there are currently no ground data available, the derived hydrographic datasets and their corresponding stream orders will be useful in estimating stream parameters and characteristics within the AOIs and subareas through remote sensing. Specific hydrologic characteristics, such as velocity differences, accompany different stream orders, and an understanding of these characteristics can improve the modeling of mineral resources in Afghanistan. Modeling of mineral resources may be helpful in predicting the location and characteristics of mineral deposits, particularly those which have been transported downstream from 
their source areas. Such models have the potential to improve mineral exploration, assessment, and management efforts, thereby reducing investment risk for government agencies, developmental organizations, and private companies.

\section{References}

Adams, K.D., and Sada, D.W., 2014, Surface water hydrology and geomorphic characterization of a playa lake system; Implications for monitoring the effects of climate change: Journal of Hydrology, $\mathrm{v}$. 510, p. 92-102, http://dx.doi.org/10.1016/j.jhydrol.2013.12.018.

Breckle, S.W., 2002, Salt deserts in Iran and Afghanistan, in Barth, Hans-Jörg, and Böer, Benno, eds., Sabkha ecosystems, Volume I; The Arabian Peninsula and adjacent countries: Dordrecht, Netherlands, Kluwer Academic Publishers, p. 109-122.

Briere, P.R., 2000, Playa, playa lake, sabkha; Proposed definitions for old terms: Journal of Arid Environments, v. 45, p. 1-7.

Casey, B.N., and Chirico, P.G., 2013, Topographic and hydrographic GIS datasets for the Afghan Geological Survey and U.S. Geological Survey 2013 mineral areas of interest: U.S. Geological Survey Open-File Report 2013-1124, 16 p., http://pubs.er.usgs.gov/publication/ofr20131124.

Chirico, P.G., Malpeli, K.C., and Trimble, S.M., 2012, Accuracy evaluation of an ASTER-derived global digital elevation model (GDEM) version 1 and version 2 for two sites in western Africa: GIScience \& Remote Sensing, v. 49, no. 6, p. 775-801, http://pubs.er.usgs.gov/publication/70047204.

Chirico, P.G., and Moran, T.W., 2011, Topographic and hydrographic GIS dataset for the Afghanistan Geological Survey and U.S. Geological Survey 2010 minerals project: U.S. Geological Survey Data Series 624, http://pubs.usgs.gov/ds/624/.

Dorsaz, Jean-Marc, Gironas, Jorge, Escauriaza, Cristian, and Rinaldo, Andrea, 2013, The geomorphometry of endorheic drainage basins; Implications for interpreting and modelling their evolution: Earth Surface Processes and Landforms, v. 38, no. 15, p. 1881-1896, http://dx.doi.org/10.1002/esp.3475.

Goudie, A.S., 1991, Pans: Progress in Physical Geography, v. 15, no. 3, p. 221-237, http://ppg.sagepub.com/content/15/3.toc.

Jenson, S.K., and Domingue, J.O., 1988, Extracting topographic structure from digital elevation data for geographic information system analysis: Photogrammetric Engineering and Remote Sensing, v. 54, no. 11, p. 1593-1600.

Joya, Omar, 2012, Natural Resources; What strategy for Afghanistan?: Kabul, Afghanistan, Samuel Hall Consulting, Policy Paper, 35 p., http://samuelhall.org/REPORTS/Natural\%20Resources\%20Strategy\%20for\%20Afghanistan.pdf.

King, T.V.V., Berger, B.R., and Johnson, M.R., 2014, Characterization of potential mineralization in Afghanistan; Four permissive areas identified using imaging spectroscopy data: U.S. Geological Survey Open-File Report 2014-1071, 67 p., http://dx.doi.org/10.3133/ofr20141071.

Lawrimore, J., and Burroughs, J., 2008, Climate of Afghanistan; National Oceanic And Atmospheric Administration National Climatic Data Center Web page, accessed December 15, 2014, at http://www.ncdc.noaa.gov/oa/climate/afghan/afghan-narrative.html. 
Neuendorf, K.K.E., Mehl, J.P., Jr., and Jackson, J.A., eds., 2005, Glossary of geology (5th ed.): Alexandria, Va., American Geological Institute, 779 p.

Peters, S.G., King, T.V.V., Mack, T.J., and Chornack, M.P., eds., and the U.S. Geological Survey Afghanistan Mineral Assessment Team, 2011, Summaries of important areas for mineral investment and production opportunities of nonfuel minerals in Afghanistan: U.S. Geological Survey Open-File Report 2011-1204, 2 vols., 1,810 p. plus appendixes on DVD, http://pubs.er.usgs.gov/publication/ofr20111204.

Peters, S.G., Ludington, S.D., Orris, G.J., Sutphin, D.M., Bliss, J.D., and Rytuba, J.J., eds., and the U.S. Geological Survey-Afghanistan Ministry of Mines Joint Mineral Resource Assessment Team, 2007, Preliminary non-fuel mineral resource assessment of Afghanistan: U.S. Geological Survey Open-File Report 2007-1214, 810 p., http://pubs.er.usgs.gov/publication/ofr20071214.

Strahler, A.N., 1964, Quantitative geomorphology of drainage basins and channel networks, in Chow, V.T., ed., Handbook of applied hydrology; A compendium of water-resources technology: New York, McGraw-Hill, p. 4-40.

Tarboton, D.G., Bras, R.L., and Rodriguez-Iturbe, Ignacio, 1991, On the extraction of channel networks from digital elevation data: Hydrological Processes, v. 5, no. 1, p. 81-100. 
ISSN 2331-1258 (online)

http://dx.doi.org/10.3133/ofr20151181 